\title{
Trace Element and Isotopic Characteristics of Olivine Melilitites from the Western Cape, South Africa: Implications for the Sources of Group 1 Kimberlites
}

\author{
Janney, P.E.1,2, le Roex, A.P.2, Viljoen, K.S.3
}

1. Scripps Institution of Oceanography, University of California, San Diego, La Jolla, CA 92093-0220, USA (email: pjanney@ucsd.edu)

2. Department of Geological Sciences, University of Cape Town, Rondebosch 7700, South Africa

3. Anglo-American Research Laboratories, PO Box 106, Crown Mines 2025, South Africa

Late Cretaceous-Early Tertiary magmatism on the southwestern margin of Africa resulted in the emplacement of three major swarms of mafic alkaline diatremes: the Gibeon kimberlite province of southern Namibia and the Namaqualand and Western Cape olivine melilitite provinces of western South Africa. The Western Cape province consists of 5 age progressive diatreme-like intrusions (Fig. 1), oriented roughly north-south, extending $360 \mathrm{~km}$ from a submarine alkali basalt plug on the Alphard Bank (58 Ma) southeast of Cape Agulhas, to the Robertson and Spiegel River olivine melilitite pipes (64 Ma) in the Cape Fold Belt, to the Sutherland and Saltpetre Kop olivine melilitite complexes (75 Ma) located in the southern Karoo (Duncan et al., 1978).

As a whole, the Western Cape melilitite/alkali basalt diatremes display large and coherent variations in their incompatible element and radiogenic isotope compositions that can be related to the age and/or thickness of the lithosphere they intrude. On the thin lithosphere of the continental shelf, the Alphard Bank alkali basalt displays incompatible element (e.g., $\left.\mathrm{La}_{\mathrm{S}} \mathrm{Sm}_{\mathrm{N}}=3.4\right)$ and isotopic characteristics $\left(87 \mathrm{Sr} / 86 \mathrm{Sri}=0.7029, \varepsilon_{\mathrm{Nd}}(\mathrm{t})=+4.6,206 \mathrm{~Pb} / 204 \mathrm{~Pb}_{\mathrm{i}}=20.4\right)$ very similar to HIMU ocean island basalts from St. Helena. On the thick Proterozoic lithosphere of the Namaqua-Natal Belt, the Saltpetre Kop melilitite, is extremely enriched in incompatible elements $\left(\mathrm{La} / \mathrm{Sm}_{\mathrm{N}}=8\right)$ displays a moderate EM 1 isotopic affinity $\left(87 \mathrm{Sr} / 86 \mathrm{Sr}_{\mathrm{i}}=0.7042, \varepsilon_{\mathrm{Nd}}(\mathrm{t})=+1.8-2.0,206 \mathrm{~Pb} / 204 \mathrm{~Pb}_{\mathrm{i}}=18.7\right)$. The Robertson, Spiegel River and Sutherland melilitites are compositionally intermediate between these two endmembers.

Unlike the those from other Western Cape localities, the melilitite diatremes from Sutherland and Saltpeter Kop display strong enrichments in $\mathrm{Ba}$, Th and the LREE (relative to $\mathrm{Nb}$ ) and depletions in $\mathrm{Zr}$ and $\mathrm{Ti}$ (relative to $\mathrm{Sm}$ ) in their primitive mantle-normalized trace element patterns. These features are prevalent in carbonatite-metasomatized peridotite, suggesting that the magmas forming the Western Cape melilitites incorporated variable amounts of metasomatized continental lithosphere during ascent. The similarity in trace element composition between these two melilitite localities and "aphanitic" Group 1 kimberlites, such as those from the Gibeon province (Spriggs, 1988), also supports the significant involvement of metasomatized lithosphere in their petrogenesis.

The isotopic variations of the Western Cape melilitites can be well explained by mixing between a HIMU source component having the chemical and isotopic composition of recycled oceanic crust (e.g., Chauvel et al., 1992) and an EM 1-like continental lithospheric component having the average composition of metasomatized peridotite xenoliths from Bultfontein (Hawkesworth et al, 1990; Fig. 2). Interestingly, the bulk of isotopic data for on- and off-craton Cretaceous Group 1 kimberlites from southern Africa (e.g., Smith, 1983; Spriggs, 1988) also clusters around this mixing curve, indicating that they also can be explained by mixing between a HIMU source and metasomatized continental lithosphere. None of the kimberlite data extend to the highly radiogenic initial $206 \mathrm{~Pb} / 204 \mathrm{~Pb}$ values $(>20)$ observed in the Western Cape diatremes intruded through the thinnest lithosphere (e.g., Alphard Bank, Robertson), presumably because of higher extents of lithospheric contamination in the thick cratonic or mobile belt settings where kimberlites occur. 
The presence of HIMU as a mixing end-member in Group 1 kimberlites and melilitites from throughout southern Africa is difficult to explain by direct derivation from one or more mantle plumes. Moreover, the fact that HIMU is most strongly expressed in magmas intruded through the thinnest lithosphere (e.g., Alphard Bank, Robertson) suggests that the HIMU source is not present in the main part of the lithosphere but rather exists as a widespread domain at its base. Ancient subducted oceanic crust, which may be present as an underplated layer beneath much of the southern African lithosphere (e.g., Taylor et al., 1987), is a good candidate for such a source domain, provided it has remained in convective isolation for the past 1-2 Ga.

As proposed for the Namaqualand melilitites (Janney and le Roex, this volume), the linear, ageprogressive expression of the Western Cape melilitites may have resulted from the action of a stationary mantle plume or hotspot as a heat source at the base of the lithosphere (e.g., Wilson et al., 1995). The melts produced would variably interact with and assimilate lithospheric mantle material during ascent, causing the observed HIMU-EM 1 compositional array.

\section{References}

Chauvel, C., A.W. Hofmann and P. Vidal, 1992, HIMU-EM: the French Polynesian connection: Earth Planet. Sci. Lett., 110, p. 99-109.

Duncan, R.A., R.B. Hargraves and G.P. Brey, 1978, Age, paleomagnetism and chemistry of melilite basalts in the Southern Cape, South Africa: Geol. Mag., 115, p. 317-396.

Hawkesworth, C.J., A.J. Erlank, P.D. Kempton and F.G. Waters, 1990, Mantle metasomatism: isotope and trace element trends in xenoliths from Kimberley, South Africa: Chem. Geol., 85, p. 19-34.

Smith, C.B., 1983, $\mathrm{Pb}, \mathrm{Sr}$ and $\mathrm{Nd}$ isotopic evidence for sources of southern African Cretaceous kimberlites: Nature, 304, p. 51-54.

Spriggs, A.J., 1988, An isotopic and geochemical study of kimberlites and associated alkaline rocks from southern Namibia: PhD Dissertation, University of Leeds.

Taylor, L.A., C.R. Neal, B. Pyle and J.W. Shervais, 1987, Underplating of the Kaapvaal Craton of southern Africa by subducted oceanic crust: evidence from diamondiferous eclogites: IUGG XIX General Assembly Abstracts, 1, p. 65.

Wilson, M., J.M. Rosenbaum, E.A. Dunsworth, 1995, Melilitites: partial melts of the thermal boundary layer?: Contrib. Mineral. Petrol., 119, p. 181-196.

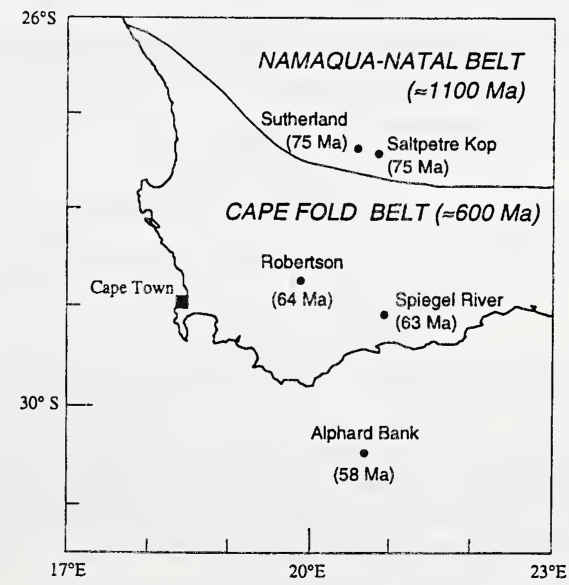

Figure 1. Map showing the locations and ages of the Western Cape diatremes and the major lithospheric provinces (with approximate stabilization ages). 


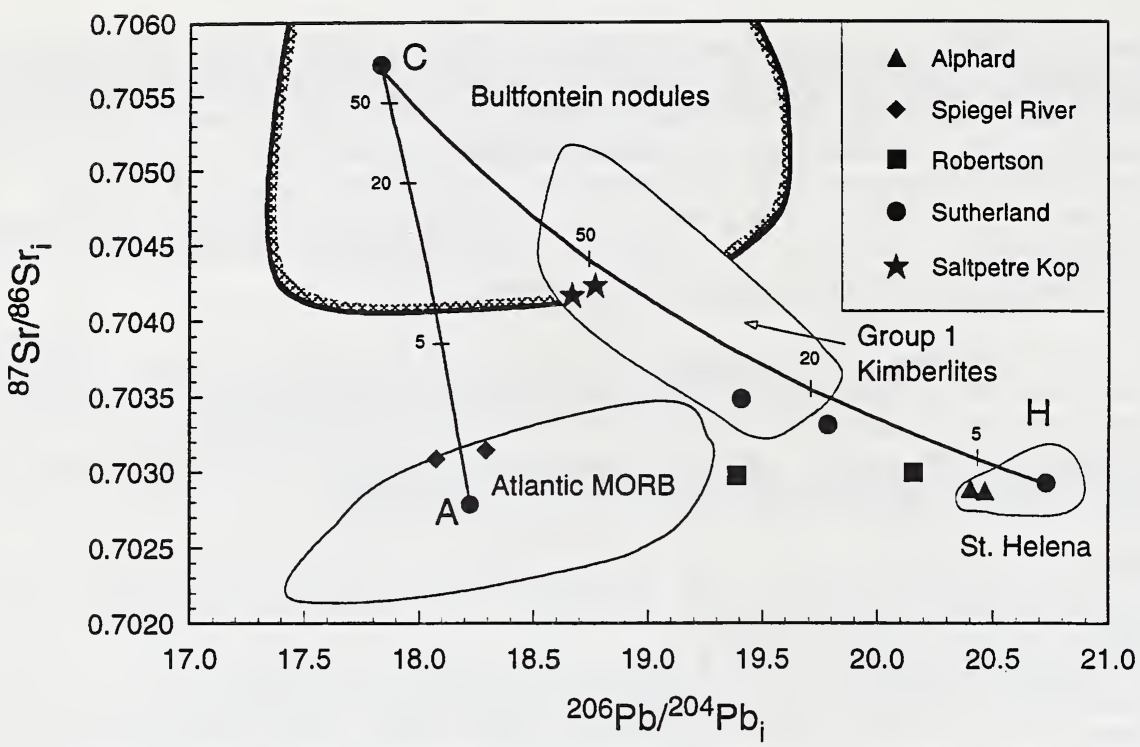

Figure 2. Sr vs. $\mathrm{Pb}$ isotope ratios for the Western Cape melilitites. Also shown are mixing curves between hypothetical HIMU $(\mathrm{H})$ and Atlantic MORB-source (A) endmembers and continental lithosphere (C). Elemental data for the endmembers is from Chauvel et al. (1992) and Hawkesworth et al. (1990).
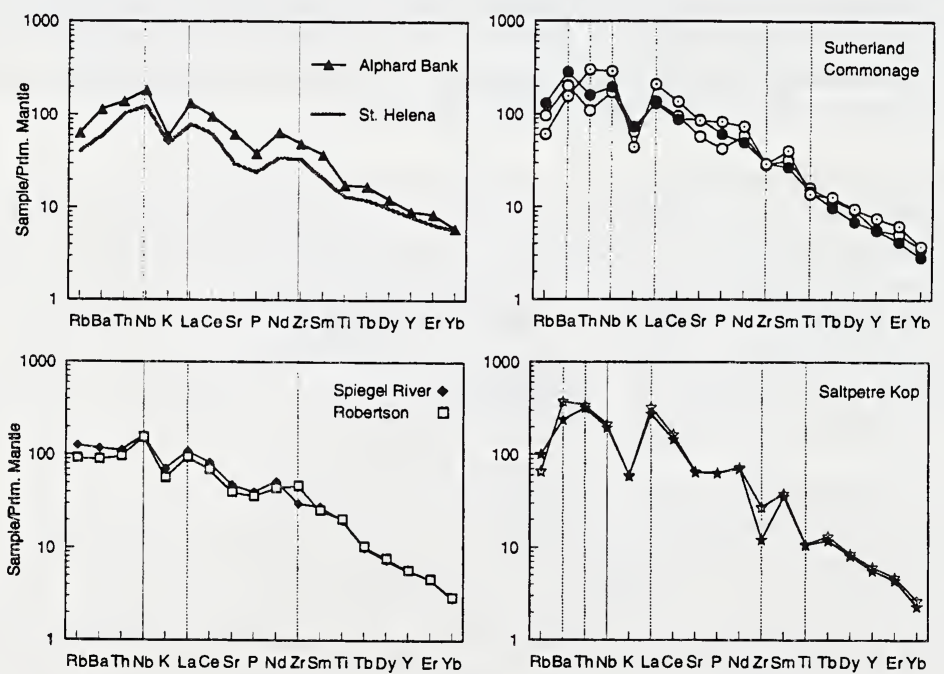

Figure 3. Incompatible element patterns of the Western Cape alkali basalt/melilitite diatremes. Note the increased relative abundances of $\mathrm{Ba}, \mathrm{Th}$ and the LREE and the relative depletions in $\mathrm{Zr}$ and $\mathrm{Ti}$ in the Sutherland and Saltpetre Kop melilitites. 